\title{
EMOTIONAL PROPERTIES IN THE SYSTEM OF COPING RESOURCES OF THE PERSONALITY
}

\author{
У статті розглянуто погляди вчених на \\ зміст копінг-ресурсів особистості в про- \\ цесі саморегуляції. Представлено резуль- \\ тати експериментального дослідження \\ особистісних емоційних властивостей $i$ \\ таких механізмів емоційної саморегуляції, \\ як копінг-стратегії. Проведено порівняль- \\ ний аналіз особливостей взаємозв'язку \\ копінг-стратегій та особистісних емо- \\ ційних властивостей у студентів та пси- \\ хологів у стресових ситуаціях. Визначено \\ кількісні та якісні характеристики зв'язків \\ копінг-стратегії втечі/уникнення 3 осо- \\ бистісними емоційними властивостями \\ у психологів і студентів. у психологів \\ копінг-стратегії конфронтації, прийняття \\ відповідальності пов'язані 3 емоційною \\ збудливістю, інтенсивністю емоцій, емо- \\ ційною лабільністю, емоційною чуйністю, \\ експресивністю, оптимістичністю. Стра- \\ тегія пошуку соціальної підтримки корелює \\ з інтенсивністю емоцій. Копінг-стратегіі \\ дистанціювання, позитивна переоцінка, \\ планування вирішення проблем не пока- \\ зали кореляційних зв'язків з емоційними \\ властивостями психологів. У студентів \\ копінг-стратегія прийняття відповідаль- \\ ності корелює з емоційною лабільністю, \\ копінг-стратегія пошуку соціальної під- \\ тримки - з показниками емочійної збуд- \\ ливості, емоційної чуйності, оптимізмом. \\ Копінг-стратегії дистанціювання, конор- \\ ронтація, позитивна переоцінка, самокон- \\ троль, планування вирішення проблем не \\ показали кореляційних зв'язків з емоційними \\ властивостями студентів. \\ Встановлені розбіжності між показниками \\ експресивності та емоційної стійкості у \\ психологів та студентів. Доведено, що \\ психологи під час стресової ситуації вико- \\ ристовують більш різноманітний репер- \\ туар копінг-стратегій у взаємозв'язку $з$ \\ емоційними властивостями порівняно зі \\ студентами під час екзаменаційної сесії. \\ Отримані результати сприяють кращому \\ розумінню механізмів емоційної саморегуляції \\ особистості, особливо в стресовій ситуації. \\ Ключові слова: копінг-стратегії, емоційне \\ збудження, глибина та інтенсивність емо- \\ цій, емоційна лабільність, інтенсивність
}

емоцій, емоційна стійкість, емоційна чуйність, експресивність, оптимістичність.

The article considers the views of scientists on the content of coping resources of the personality in the process of self-regulation. The results of the experimental research of personal emotional properties and such mechanisms of emotional self-regulation as coping strategies are presented. The comparative analysis of the interrelation between coping strategies and personal emotional properties in students and psychologists in stressful situations is carried out. The quantitative and qualitative characteristics of the connections between the coping strategies of escape-avoidance and the personal emotional properties of psychologists and students are determined. In psychologists, the coping strategies of confrontation, acceptance of responsibility are associated with emotional excitability, emotional intensity, emotional lability, emotional sensitivity, expressiveness, optimism. The strategy of seeking social support correlates with the intensity of emotions. The coping strategies of distancing, positive reassessment, problem-solving planning has not shown correlations with the emotional properties of psychologists. In students, the coping strategies of taking responsibility correlates with emotional lability, the coping strategy of seeking social support with indicators of emotional excitability, emotional sensitivity, optimism. The coping strategies of distancing, confrontation, positive reassessment, self-control, problem-solving planning has not shown correlations with students' emotional properties. The differences between the indicators of expressiveness and emotional stability in psychologists and students are determined. It is proved that psychologists use a more diverse repertoire of coping strategies in interrelation with their emotional properties during a stressful situation than students do during the examination session. The results obtained contribute to a better understanding of the mechanisms of emotional self-regulation of the personality, especially in a stressful situation

Key words: coping strategies, emotional excitability, depth and intensity of emotions, emotional lability, emotional intensity, emotional stability, emotional sensitivity, expressiveness, optimism.
Постановка проблеми. Проблема особистісної (психічної) регуляції поведінки в критичних, стресових ситуаціях зводиться до кількох напрямів вивчення. Це визначення основних рис або типів особистості, що характеризують поведінку в цих умовах, а також адаптаційне значення тих чи інших особистісних властивостей, ролі особистості в подоланні впливів, що її травмують, взаємозв'язку особистісних властивостей суб'єкта з іншими його властивостями в процесах регуляції поведінки.

В умовах фрустрації, психічної напруженості ресурси особистості забезпечують мож- ливість побудови інтегрованої поведінки, дають змогу зберегти її цілеспрямованість, співвідносити власні потреби й вимоги оточення [1]. Особливості ресурсів особистості сприяють вибору цілком певних копінг-стратегій, які реалізує людина в критичних життєвих ситуаціях.

Терміни «психологічні ресурси», «особистісні ресурси», «адаптаційні ресурси» в психології застосовуються для позначення широкого кола біоенергетичних, інтелектуальних, характерологічних, вольових якостей особистості, властивостей їі оточення, системи 
її відносин у соціумі. Результатом наукової рефлексії в цьому напрямі стало виділення особистісних характеристик, які або сприяють або перешкоджають індивіду впоратися з важкими, критичними ситуаціями на своєму життєвому шляху [2].

Аналіз останніх досліджень і публікацій. Д.О. Леонтьєв розглядає особистісні ресурси як компонент особистісного потенціалу. Поняття особистісного потенціалу визначається автором як система особистісних факторів, що визначають успішність саморегуляції в різних ситуаціях діяльності. Ресурси, що найбільш часто виявляються в різноманітних ситуаціях, Д.О. Леонтьєвим позначені як метаресури. Вони включають три глобальних класи, а саме фізіологічні, психологічні та соціальні ресурси. До психологічних ресурсів автор відносить психологічні ресурси стійкості (ціннісно-смислові ресурси, зокрема задоволеність життям, осмисленість життя); психологічні ресурси саморегуляції, тобто стійкі стратегії побудови взаємодії зі світом (каузальні орієнтації, локус контролю, ефективність, толерантність до невизначеності, схильність до ризику, поленезалежність, рефлексія); мотиваційні ресурси; інструментальні ресурси, тобто навички та компетенції, набуті в процесі життєдіяльності [3].

Слід зауважити, що історія вивчення копінгу відображає певне протистояння ситуаціонізму і теорії рис. Як досліджувану область поведінки опанування ситуаціонізм визначав зовнішні фактори середовища, теорія рис індивідуально-психологічні відмінності, особистісні властивості. Відповідно, дослідники або роблять акцент на видах стратегій у критичних ситуаціях, або ідентифікують основні копінгстилі як звичні способи, що використовуються індивідами в стресових ситуаціях [4].

В.О. Бодров одним із перших психологів застосував ресурсний підхід до вивчення регуляції інформаційного стресу та розумів ресурси у таких трьох аспектах:

- як цілком визначене об'єктивно реєстроване матеріальне явище (наприклад, ресурсом може виступати активуюча функція ретикулярної формації, змінення кровотоку або процеси метаболізму глікопротеїну в мозку);

- як теоретичний конструкт, що відбиває деяку ідеальну якість, притаманну системі оброблення інформації, яка характеризує ії властивість обмеженості та розподілу засобів оброблення інформації, що робить принципово можливим оцінювання невикористаних ресурсів, тобто резервів оброблення інформації;

- як функціональний потенціал, що забезпечує сталий рівень виконання вихідних показників протягом певного часу [5].
О.О. Сергієнко запропонувала виділяти в системі особистісних ресурсів дві підсистеми, а саме зовнішні та внутрішні ресурси, кожні з яких мають рівневу організацію. Підсистема зовнішніх ресурсів представлена ресурсами фізичного середовища й ресурсами соціального середовища. Підсистема внутрішніх ресурсів включає рівні фізіологічних і психодинамічних властивостей, когнітивний рівень, ціннісно-смисловий і «верховий» рівні. До останнього рівня віднесені три ключові якості людини, які безпосередньо пов'язані з ефектом долання, такі як самоефективність, стійкість і витривалість. Емоційні (інтенсивність емоцій, імпульсивність, лабільність, домінуюча «забарвленість» настрою) і вольові (здатність підпорядкувати поведінку цілям, стандартам, сенсам) ресурси, доповнюючи когнітивні, складають «ресурсну основу контролю поведінки» [6].

Однією з найбільш поширених класифікацій ресурсів є класифікація С. Хобфола. Відповідно до цієї класифікації, ресурси можуть бути позначені як матеріальні об'єкти (дохід, житло, одяг, матеріальні фетиші) й нематеріальні (бажання, цілі); зовнішні (соціальна підтримка, сім'я, друзі, робота, соціальний статус) і внутрішні, інтраперсональні змінні (самоповага, професійні уміння, навички, здібності, інтереси, самоконтроль, оптимізм, життєві цінності, система вірувань); психічні та фізичні стани; вольові, емоційні та енергетичні характеристики, які необхідні для подолання важких життєвих ситуацій і досягнення особистісно значущих цілей. Велика частина досліджень копінгу традиційно центрована на аналіз «внутрішніх» чинників переваги форми долання.

Цікавою $€$ систематизація внутрішніх ресурсів особистості, яку запропонували І.П. Шкуратова і О.А. Анненкова [7]. Сукупність особистісних ресурсів дослідниці об'єднали в п'ять таких основних груп: світогляд і вірування людини, сила духу; інтелект, креативність, інтерес до світу; системи навичок, умінь, знань; енергетичний ресурс; властивості особистості, спрямовані на протистояння руйнівним діям (життєстійкість, цілеспрямованість, оптимізм, локус контролю).

У низці робіт вітчизняних дослідників обґрунтовано необхідність звернення до виявлення особистісниххарактеристик, що роблять найбільший вплив на процес самоздійснення суб'єкта в умовах соціально-психологічної адаптації. Йдеться про такі характеристики, як активність, оптимістичність, інтернальність локус-контролю, креативність, висока установчо-цільова вмотивованість і конструктивність в поведінці діяльності та спілкуванні.

Особливий акцент ставиться на ролі активності як найважливішому ресурсі осо- 
бистості. На думку В.Д. Небиліцина, активність $€$ ядром функціонального стану людини й служить спонукальною силою мотиваційного статусу людини. Л.Н. Собчик вважає, що активність і сила особистості складають емоційно-динамічний патерн індивіда, що уходить своїм корінням в тип вищої нервової діяльності й властивості нервової системи. Емоційно-динамічний патерн відіграє важливу роль у формуванні базисних індивідуально-особистісних властивостей, структура яких визначається провідною тенденцією або декількома тенденціями, що додають індивідуальне забарвлення й певну якісну специфіку стилю переживань, мислення, міжособистісної поведінки, основної спрямованості та силі мотивації. Більш того, формуючи характер людини, провідні тенденції емоційно-динамічного та індивідуально-особистісного патерну певною мірою обмежують русло, в рамках якого формуються вищі рівні особистісного розвитку, створюючи певну вибірковість і тропізм щодо тих чи інших цінностей, а також можливих варіантів напрямів соціальної активності [1].

Отже, дослідники одностайні у визнанні особистісної детермінації процесів саморегуляції та поведінки опанування. Очевидно, що ця поведінка визначається і регулюється спрямованістю особистості, її життєвими цінностями, мотивами, моральністю, свободою вибору, інтелектуально-творчими та психоемоційними ресурсами в найважчих життєвих ситуаціях.

Постановка завдання. Метою статті $€$ порівняльний аналіз особливостей взаємозв'язку копінг-стратегій та емоційних властивостей у психологів та студентів.

Виклад основного матеріалу дослідження. Нами було здійснено дослідження взаємозв'язку копінг-стратегій, емоційних властивостей психологів та студентів у стресових ситуаціях.

Задля дослідження копінг-стратегій було використано копінг-тест Р. Лазаруса. Для дослідження емоційних властивостей, відповідно до характеристик емоційного реагування Є.П. Ільїна, було використано шкали «емоційна збудливість», «інтенсивність емоцій», «емоційна стійкість» самооціночного тесту «Характеристики емоційності» Є.П. Ільїна; шкала «емоційна лабільність» Фрайбургського опитувальника; шкала «емоційна чуйність» методики «Емоційний канал емпатії» В.В. Бойко; шкала «експресивність» методики емоційно-енергетичних зарядів В.В. Бойко; шкала «оптимістичність» чотирьохмодального емоційного опитувальника Л.А. Рабиновича.

У результаті аналізу показників встановлені кореляційні зв'язки між копінг-стратегіями та емоційними властивостями психологів. Так, існують прямі кореляційні зв'язки між показниками копінг-стратегії «конфронтація» та показниками таких особистісних емоційних властивостей, як «емоційна збудливість» $(r=0,380)$, «інтенсивність емоцій» $(r=0,324)$, «емоційна лабільність» $(r=0,325)$, «емоційна чуйність» $(r=0,325)$, «експресивність» $(r=0,383)$, «оптимістичність» $(r=0,407)$. За умов реагування на стрес стратегією конфронтації у психологів посилюються активність, енергійність, але їх дії втрачають свою цілеспрямованість унаслідок емоційного входження в ситуацію. Самі стресові ситуації дають багато приводів психологам для обурення, невдоволення, гніву, розчарування. Вони втрачають душевну рівновагу, у них часто псується настрій, находить смуток, нудьга. Вони відчувають внутрішню напруженість, невдоволення, гнів, тривожність, але намагаються не показувати свої переживання оточуючим.

Існують прямі кореляційні зв'язки між показником копінг-стратегії "самоконтроль» та показниками таких емоційних властивостей психологів, як «інтенсивність емоцій» $(r=0,363)$, «емоційна лабільність» $(r=0,408)$, «експресивність» $(r=0,461)$, «Оптимістичність» $(r=0,531)$. Завдяки стратегії самоконтролю психологи долають негативні переживання, стримують емоції, приховують їх від оточуючих. Однак інтенсивність емоційного реагування на стресову ситуацію в психологів достатньо висока. Майже завжди вони перебувають у стані мобілізації для віддзеркалення загрози, неприємностей, негативних переживань. Вони сильно хвилюються, приймають все близько до серця. У них досить часто змінюється настрій, вони швидко втомлюються, але вірять у свої сили, достатньо впевнені й повні оптимізму.

Встановлено прямі кореляційні зв'язки між показником копінг-стратегії «прийняття відповідальності» та показниками емоційних властивостей психологів, таких як «інтенсивність емоцій» $(r=0,392)$, «емоційна лабільність» $(r=0,312)$, «емоційна чуйність» $(r=0,312)$, “експресивність» $(r=0,376)$, «емоційна стійкість» $(r=0,449)$, «оптимізм» $(r=0,314)$. Використання стратегії прийняття відповідальності приводить психологів до розвитку почуття пригніченості та залежності від стресових обставин. Вони відчувають відчай, депресивність, безпорадність, дратівливість. У професійній діяльності вони фокусують свою увагу на власній некомпетентності, виявляють ознаки нервозності, неспокою, пригніченості. Стресові обставини зобов'язують психологів стримувати себе, але вони відчувають скутість і напруження, занурюються у свої переживання. Інколи у психологів виникає відчуття, що майбутнє може бути безперспективним і похмурим. 
Найбільшу кількість прямих кореляційних зв'язків встановлено між копінг-стратегією «втеча/уникнення» та показниками таких емоційних властивостей психологів, як «емоційна збудливість» $(r=0,423)$, «інтенсивність емоцій» $(r=0,413)$, «емоційна лабільність» $(r=0,393)$, «емоційна чуйність» $(r=0,432)$, «експресивність» $(r=0,450)$, «емоційна стійкість» $(r=0,342)$, «оптимістичність» $(r=0,547)$. Не маючи можливості осмислити стресову ситуацію, психологи відчувають тривогу, емоційне напруження, емоційне збудження, запальність. Їх емоційне реагування досить тривале та інтенсивне, вони часто переживають, хвилюються, не можуть залишатися спокійними, відгукуються на проблеми інших. Однак психологи в стресових ситуаціях прагнуть зберегти свої сили, намагаються стримувати себе, зберігають надії на позитивний результат.

Існує прямий кореляційний зв'язок між показником копінг-стратегії «пошук соціальної підтримки» та показником «інтенсивність емоцій» ( $r=0,309)$. За активної взаємодії з іншими людьми психологи емоційно включаються в стресову ситуацію, роблять спроби вирішити проблеми за рахунок пошуку інформаційної та емоційної підтримки. Вони готові звернутися за рекомендаціями до інших психологів задля набуття необхідних знань. Сильні та інтенсивні негативні емоційні переживання вони прагнуть обговорювати з іншими задля послаблення своєї емоційної напруги та переживань.

Копінг-стратегії «дистанціювання», «позитивна переоцінка», «планування вирішення проблем» не показали кореляційних зв'язків з емоційними властивостями психологів.

За результатами проведеного нами дослідження ми можемо зробити висновки, що вибір копінг-стратегій психологами у стресовій ситуації значною мірою визначається емоційними властивостями. Особливо значний взаємозв'язок простежується між показниками копінг-стратегіями й такими емоційними властивостями, як експресивність, оптимістичність, емоційна лабільність та інтенсивність емоцій. Вивчення зв'язків копінг-стратегій з емоційними властивостями може сприяти кращому розумінню механізмів емоційної саморегуляції особистості, особливо в стресовій ситуації.

У студентів найбільшу кількість прямих кореляційних зв'язків встановлено між копінг-стратегією «втеча/уникнення» та показниками таких емоційних властивостей, як «емоційна збудливість» $(r=0,335)$, «емоційна лабільність» $(r=0,505)$, «емоційна чуйність» $(r=0,382)$, «експресивність» $(r=0,329)$. Завдяки стратегії «втеча/уникнення» студенти роблять спроби подолати негативні емоційні переживання у стресовій ситуації шляхом ухилення від труд- нощів без прагнення осмислити саму ситуацію. Вони ігнорують проблеми, які виводять їх із рівноваги. Студенти виявляють ознаки нервозності, спалахи роздратування на тлі збереження надії на позитивний результат.

Встановлено прямі кореляційні зв'язки між показником копінг-стратегії «прийняття відповідальності» та показником емоційних властивостей студентів «емоційна лабільність» $(r=0,322)$. У стресовій ситуації студенти роблять спроби викликати до себе поблажливість, орієнтуються на зовнішню оцінку. Вони відчувають невпевненість, почуття провини з депресивним відтінком, тривожністю, пригніченістю. У них досить часто змінюється настрій, вони швидко втомлююся. Будь-яка діяльність стає для них важкою, протікає з надмірними психічними напруженнями.

Існує прямий кореляційний зв'язок між показником копінг-стратегії «пошук соціальної підтримки» та показниками стратегій «емоційна збудливість» $(r=0,302)$, «емоційна чуйність» $(r=0,396)$, «оптимізм» $(r=0,401)$. Підчас стресової ситуації студенти активно взаємодіють з оточуючими, зосереджені на спробах вирішення проблем. Вони виявляють активність у пошуку інформаційної підтримки задля подолання стану невизначеності, емоційної збудливості, ознаки нервозності, неспокою. Студенти оптимістичні й вірять у свої сили, незважаючи на потребу в емоційній підтримці.

Копінг-стратегії «дистанціювання», «конФронтація», «позитивна переоцінка», «самоконтроль», «планування вирішення проблем» не показали кореляційних зв'язків з емоційними властивостями студентів.

За результатами проведеного нами дослідження ми можемо зробити висновки, що вибір копінг-стратегій студентів у стресовій ситуації визначається емоційними властивостями, але менше, ніж у психологів. Особливо значний взаємозв'язок простежується між показниками копінг-стратегій і такими емоційними властивостями, як емоційна збудливість, емоційна лабільність, емоційна чуйність.

В результаті аналізу за t-критерієм Стьюдента розбіжності між показниками емоційних властивостей у психологів та студентів досягають рівня значущості. Так, у психологів та студентів розбіжності показників стратегій «експресивність» $(\mathrm{t}=-2,78 ; \mathrm{p}<0,001)$ та «емоційна стійкість» $(t=-5,37 ; p<0,001)$ значущі. Треба зазначити, що у психологів більш визначені, ніж у студентів такі емоційні властивості, як експресивність та емоційна стійкість. Психологи, перебуваючи у стресових ситуаціях, можуть мобілізуватися для утримання своїх негативних емоційних переживань. Відчуваючи невдоволення, розчарування, напруження, психологи намагаються не показувати свої переживання оточуючим. 
Висновки 3 проведеного дослідження. Вибір копінг-стратегій у стресовій ситуації значною мірою визначається емоційними властивостями особистості. Під час стресової ситуації психологи використовують широкий репертуар копінг-стратегій поведінки. Існує значна кількість кореляційних зв'язків між показниками копінг-стратегій та показниками емоційних властивостей психологів (емоційна збудливість, інтенсивність емоцій, емоційна лабільність, емоційна чуйність, експресивність, оптимістичність). Найбільшу кількість взаємозв'язків з особистісними емоційними властивостями утворює копінг-стратегія «втеча/уникнення» як у психологів, так і у студентів. У психологів стратегії «конфронтація», «прийняття відповідальності» пов'язані з такими особистісними емоційними властивостями, як емоційна збудливість, інтенсивність емоцій, емоційна лабільність, емоційна чуйність, експресивність, оптимістичність. Стратегія пошуку соціальної підтримки корелює з інтенсивністю емоцій. Копінг-стратегії «дистанціювання», «позитивна переоцінка», «планування вирішення проблем» не показали кореляційних зв'язків з емоційними властивостями психологів.

У студентів копінг-стратегія «втеча/уникнення» пов'язана з такими особистісними емоційними властивостями, як емоційна збудливість, емоційна лабільність, емоційна чуйність, експресивність. Копінг-стратегія «прийняття відповідальності» пов'язана з емоційною лабільністю. Копінг-стратегія «пошук соціальної підтримки» пов'язана з показниками емоційних властивостей «емоційна збудливість», «емоційна чуйність», «оптимізм». Копінг-стратегії «дистанціювання», «конфронтація», «позитивна переоцінка», «самоконтроль», «планування вирішення проблем» не показали кореляційних зв'язків з емоційними властивостями студентів. Розбіжності між показниками емоційних властивостей «експресивність» та «емоційна стійкість» значущі в психологів та студентів. Отримані взаємозв'язки копінг-стратегій з емоційними властивостями дають змогу скласти цілісний конструкт емоційної саморегуляції особистості.

Перспективними у цьому напрямі вважаємо дослідження розширеного репертуару емоційних властивостей особистості та їх зв'язку з такими механізмами емоційної саморегуляції, як механізми психологічного захисту.

\section{ЛІТЕРАТУРА:}

1. Исаева Е.Р. Копинг-поведение и психологическая защита личности в условиях здоровья и болезни : монографрия. Санкт-Петербург : Издательство СПбГМУ, 2009. 136 с.

2. Анцыферова Л.И. Личность в трудных жизненных условиях: переосмысливание, преобразование ситуаций и психологическая защита. Психологический журнал. 1994. Т. 1. № 1.

3. Леонтьев Д.А. Психологические ресурсы преодоления стрессовых ситуаций: к уточнению базовых понятий. Психология стресса и совладающего поведения : материалы II Международной научно-практической конференции. Кострома : КМУ им. Н.А. Некрасова, 2010. С. 40-42.

4. Крюкова Т.Л. Психология совладающего поведения: современное состояние и психологические, социокультурные перспективы. Вестник КГУ им. Н.А. Некрасова. 2013. № 5. С. 184-188.

5. Бодров В.А. Информационный стресс : учебное пособие для вузов. Москва : ПЕР СЭ, 2000. 352 с.

6. Сергиенко Е.А. Контроль поведения как основа саморегуляции. Южно-российский журнал социальных наук. 2018. Т. 19. № 4. С. 130-146.

7. Шкуратова И.П., Анненкова Е.А. Психология кризиса и кризисных состояний. Междисциплинарный ежегодник. 2007. Вып. 4. С. 17-23. 